\title{
IMPACT OF DYEING INDUSTRIAL POLLUTION ON FARM INCOME AND PRODUCTION IN TIRUPPUR DISTRICT OF TAMIL NADU
}

\author{
S. Gandhimathi* \\ and \\ N.Dhanabaghiyam ${ }^{* *}$
}

\begin{abstract}
India targeted to achieve 3-4 per cent growth per annum in agricultural sector and to produce 400 million tonnes of foodgrains by 2020. To achieve this target the strategies of the green revolution are not valid. The high usage of fertilisers and chemicals did not increase the productivity of agriculture. They had caused environmental degradation. Hence, there is a need to identify new strategies to achieve the goals. Environmental degradation is one of the most pronounced problems in agriculture. The industrial pollution is a major cause of environmental degradation. The growing industries had aggravated the problems of environmental degradation in agriculture.

Hence, the policies which promote sustainable agriculture, in terms of food security, rural employment and environmentally sustainable technologies are needed. The findings of the study showed that all the farmers (cent percent) had responded that the dumping of industrial waste was the major cause of industrial pollution in agriculture. The quality of land was completely eroded and the crops were burnt due to dyeing industrial pollution. It was not able to use for drinking water of the farmers and livestock. If one additional farmer had cultivated in an area polluted industries, the farm income had reduced to the extent of ₹ 3,24,644.196. Moreover, the farmers in polluted area were not able to allocate farm inputs more efficiently. Hence less technical efficiency was observed in the production function of polluted area.
\end{abstract}

\footnotetext{
*Associate Professor of Economics, Avinashilingam Institute for Home Science and Higher Education for Women, Coimbatore, Tamil Nadu.

**M.A. Economics, Avinashilingam Institute for Home Science And Higher Education for Women, Coimbatore, Tamil Nadu.
}

Journal of Rural Development, Vol. 36, No. 2, April - June: 2017 


\section{Introduction}

Agriculture is the major source of livelihood in India. The country has taken notable strides in the agricultural sector during the last five and half decades of economic planning. The share of agriculture in total Gross Domestic Product (GDP) was around 14 percent in 2011 2012. The value of GDP in agriculture was ₹ 2 , 796.18 crore in1950 -1951. It had shown an increasing trend and reached ₹ 52, 025.14 crore in 2011-2012. However, the share of agricultural GDP in total GDP had shown a decreasing trend by recording 51.88 per cent in $1950-1951$ and 14.01 per cent in 2011-12 (Hand Book of Indian Economy, 2013). The growth rate of net sown area had declined from 12.2 percent during 1950 - 1951 to 1960 - 1961 to -0.4 per cent during $2000-2001$ to $2007-2008$. The growth rates of gross and net irrigated areas between 1960 1961 and 1990 -1991 witnessed an increase of 3 and 5.8 percentage points, respectively, whereas between 1990-1991 and 2007-2008, the growth rates reduced by 12.3 and 10.9 percentage points, respectively (Chakrabarty, 2011).

The gross domestic product was not correlated with the growth of agriculture in the $7^{\text {th }}$ Plan period. It means that the growth of GDP was not because of growth of agriculture and it was attributed to other sectors in the $7^{\text {th }}$ Plan period. Moreover, a target of 4 per cent growth rate was fixed in the agriculture sector. Only 2.5 per cent was achieved in the $10^{\text {th }}$ Five Year Plan. The agriculture and allied sectors registered an average annual growth rate of 2.03 per cent during the first three years of the $11^{\text {th }}$ Five Year Plan. It revealed that the target growth rate in agricultural sectorwasnot achieved in the above Plan periods. India produced 21.6 per cent of the world's paddy but the productivity was less than the neighbouring countries of Bangladesh and Myanmar in 2008. The low agricultural productivity in India was attributed to low level of public investment, exhaustion of yield potential by high-yielding varieties, environmental degradation and unbalanced usage of fertilisers, etc. (State of Indian Agriculture Report 2011-12: 2012).

India targeted to achieve 3-4 per cent growth per annum in agricultural sector and to produce 400 million tonnes of foodgrains by 2020. To achieve this target, the strategies in the green revolution are not valid. The high usage of fertilisers and chemicals did not increase the productivity of agriculture, which had caused environmental degradation. Hence, there is a need to identify new strategies to achieve the goals. In this background, environmental degradation is one of the most pronounced problems in agriculture. The industrial pollution is a major cause of environmental degradation. The growing industries had aggravated the problems of environmental degradation in agriculture. The number of factories in India had increased from 127957 in 2002-03 to 158877 in 2009-10. Industries consume 37 per cent of the world's energy and emit 50 per cent of world's $\mathrm{CO}_{2}, 90$ per cent of world's $\mathrm{SO}_{2}$ and nearly all of its toxic chemicals. The growing of industries had polluted water and air.The polluted air and water had adversely affected the agricultural production. The industrial development led to increase in the $\mathrm{CO}_{2}$ emissions in India.

Hence, the policies which promote sustainable agriculture, in terms of food security, rural employment and environmentally sustainable technologies such as soil conservation, sustainable natural resource management and biodiversity protection are essential for holistic rural development. Any efforts to reduce poverty must aim at improving the agriculture by reducing the environmental 
problems. In this backdrop, an attempt is made to analysetheimpact of dyeing industrial pollution on agricultural production in the State of Tamil Nadu. The following are the specific objectives of the study.

\section{Objectives}

1. To assess the types of pollution and consequences of industrial pollution in the study area

2. To analyse the impact of dyeing industrial pollution on farm income and production.

\section{Review of Literature}

John Morton (2007) reported that the impact of climate change on agriculture isfelt in both developed and developing countries. Ithad reduced the agricultural production and productivity. Considerably more framework is needed to measure the impact of climatechange on agriculture.

Maharajan and Kirubakaran Samual (2010) studied the impact of environmental pollution on agriculture. The study was conducted in Tuticorin industrial town area. Twelve major industries were located in the district. They were engaged in the production of cotton, stapleyarn, caustic soda, PVC resin, fertilisers, soda ash, liquid carbon-di-oxide gas, etc. The study revealed that industrial disposals and other chemical contamination entered into the agricultural water sources affected agricultural production. It caused low production and productivity. The environmental pollution caused health disorders such as irritation, deftness, allergy, unhygienic condition, respiratory problems and diarrhoea. The developing countries like India should be instrumental in raising societal concerns about environmental problems.
Dhurjati Mukherjee (2012) stated that after 2050 temperature in India is expected to rise by $3-4^{\circ}$ over current levels and rainfall would become heavier, more intense and erratic and less regular.It would affect the agriculture more severely. There is a possibility of extreme maximum and minimum temperature all over the country due to increase in greenhouse gas concentrations.This is an important finding from the point of view of agriculture as the mid-day temperature increase enhances the saturation deficit of the plants.

Ratna Reddy and Bhagirath Behera (2005) assessed the impact of water pollution on agriculture. They analysed the economic costs of water pollution in terms of loss of agricultural production and incomefrom livestock. The study was based on primary data collected from polluted and non-polluted areas in Andhra Pradesh. It revealed that the cost due to pollution was higher. Passing of laws alone would not reduce the industrial pollution.

Shivkumar (2012) assessed the environmental challenges and issues of Indian agriculture. He reported that the future agriculture productivity growth may be challenged by the environmental problems such as land degradation, groundwater depletion, waterlogging and excessive use of chemical inputs. To face these challenges, policy measures must lay emphasis on organic farming.

Shabir Ahmad Padder (2013) had analysed the impact of climate change on agriculture in India. According to him, an increase of temperature from 1 to $4^{\circ} \mathrm{C}$ reduced the grain yield of rice by $0-49$ per cent, potato by $5-40$ per cent, soyabean by $11-36$ percent and green gram by 13-30 per cent. Climate change shortened rabi season. It increased vulnerability to diseases 
and pest attack. High temperatures restrict the quality of produce. They caused to decline in the milk production. India lost 1.8 million tonnes of milk production due to climate stresses.

\section{Methodology}

Study Area: Tirup pur is an industrially advanced district of Tamil Nadu. More than 80 per cent of farmers in the district are marginal and small. The total area under cultivation in the district is 228556 hectares.The major food cropsare paddy, millets and pulses.The non-food cropscultivated in the district are cotton, oilseeds and coconut. The major dams in the district are Amaravathi, Thirumoorthy, Upparu, Nallathangal, Vattamalaikarai Odai and Noyyal Orathuppalayam.

Tiruppuris an important knitwear centre in India. More than 9000 small scale units are functioning in Tiruppur. It accounts for one-third of the total apparel exports from India. By 2005, there were more than 729 bleaching and dyeing units in Tiruppur.In the processing of dyeing and bleaching, very harmful bleaching liquids, soda ash, caustic soda, sulphuric acid, hydrochloric acid, sodium peroxide and various dyesand chemicals are used by the textile industries in Tiruppur. The chemicals are not retained in the finished hosiery goods. They are discharged as wastewater. It dissolves solids which increase the biological and chemical oxygen demand in water. As no fresh water is available for dilution, the ground water in Tiruppur is not suited for irrigation. There are 28,596 farmers in 68 villages in the Noyyal River ofTiruppur affected byTiruppur industrial clusters.

Sample Selection and Collection of Data: The data for the study is primary in nature. The sampling technique adopted in the study was multi-stage sampling. In the first stage, various blocksin Tiruppurdistrict such as Gudimangalam, Udumalpet, Palladam, Pongalur, Tiruppur, Kundadam, Dharapuram, Kangeyam and Madathukulam were considered. Among these, Kangeyam block was selected for the study. In Kangeyam block, the Noyyal Orathuppalayam dam and a reservoir called Orathuppalayamdam is located on the Noyyal river between Chennimalai and Kangeyam in Orathuppalayam of Tiruppur district. The dam is situated $16 \mathrm{~km}$ north of Kangeyam and $26 \mathrm{~km}$ east of Tiruppur. It was built in 1992. Around 10,000 acres are irrigated in Tiruppur and Karur districts through this dam. After the dam was constructed, the dam water wasused for irrigation by the farmers only for five years. After that the dam became the storage tank for the textile effluents. The farmers stopped taking water for irrigation from the dam. The farmers of Orathuppalayam hamlet under Kodumanal village were also such affected group of dyeing industrial pollution. Moreover, the farmers of this hamlet filed a case in the High Court. The Pollution Control Board (PCB) also declared Orathuppalayam as a highly polluted hamlet. Hence, Orathuppalayam hamlet in Kodumanal village was selected in the next stage of multi-stage sampling. The village administrative office of Kodumanal was approached to collect the names of the farm householdsin Orathuppalayam hamlet. From the list of farm households, 50 farmers were selected randomly to form the target group. For the purpose of the study,Madhappur village which was not affected by the dyeing industrial pollution was also selected. Madhappur village is far away from the dyeing industrial pollution. From the list of names provided by the village administrative office of the Madhappur village, 50 farm households were selected based on 
random sampling method to form the control group. Hence, the sample size was one hundred.

In the post-stratification, it wasfound that out of 50 farmers, 3 were marginal with less than 1 hectare of land holding, 10 were small farmers with 1-2 hectares of land, 31 were semi-medium farmers who had land between $2-4$ hectares and 6 farmers were medium and large farmers with landholdings of 4-10 hectares and above in the polluted area. In the non-polluted area, out of 50 farmers 7 farmers were marginal, 6 farmers were small, 23 farmers were semi-medium and 14 were medium and large farmers. Survey method was used to collect information from the target and control group of farmers. Interview schedules were used to collect information on socioeconomic profile of the farmers, farm assets, farm income, farm expenditure, details regarding cropping pattern, types of industrial pollution, causes and effects of industrial pollution on agriculture, etc.

\section{Specification of Econometric Model}

The linear multiple regression model was specified to analyse the impact of dyeing industrial pollution on area under cultivation and farm income.The test was applied to assess the mean difference in the selected economic and farm related factors between polluted and nonpolluted areas.

To measure the association between industrial pollution and farm sector,Mann Whitney $Z$ test was more suitable as the samples were independent.The frontier production functions were estimated for polluted and non-polluted areas and were compared to assess the impact of industrial pollution on production function. In the earlier studies, the frontier production function and Mann Whitney $Z$ test were rarely used to assess the association between industrial pollution and farm sector.

\section{Multiple Regression Analysis}

Multiple regression equation was specified to assess the impact of industrial pollution on farm income. The form of the equation estimated in the study was

$\mathrm{Y}=\beta_{0}+\beta_{1} \mathrm{X}_{1}+\beta_{2} \mathrm{X}_{2}+\beta_{3} \mathrm{X}_{3}+\beta_{4} \mathrm{X}_{4}+\beta_{5} \mathrm{X}_{5}+\mu$

Where,

$$
\text { Y=Farm income (In ₹) }
$$

$X_{1}=$ Presence and absence of industrial pollution $(0=$ absence of industrial pollution, $1=$ presence of industrial pollution)

$X_{2}=$ Age of the farmer head (Age in years)

$X_{3}=$ Asset holding ( $\ln$ ₹)

$\mathrm{X}_{4}=$ Farm expenses (In ₹)

$X_{5}=$ Area under cultivation (In hectares)

$\mathrm{U}=$ Error term

Frontier Production Function:

The frontier production function was estimated to analyse the impact of industrial pollution on agricultural productivity. The form of the frontier production function used in the study was

$$
\begin{aligned}
& \operatorname{Ln}(y)=\beta_{\mathrm{o}}+\beta_{1} \operatorname{Ln} X_{1}+\beta_{2} \operatorname{Ln} X_{2}+\beta_{3} \operatorname{Ln} X_{3}+\beta_{4} \operatorname{Ln} X_{4} \\
& +\beta_{5} \operatorname{Ln} X_{5}+V_{i t} \\
& Y=\text { Value of yield (In ₹) } \\
& X_{1}=\text { Value of labour (In ₹) }
\end{aligned}
$$


$X_{2}=$ Value of seeds ( $\ln ₹$ )

$\mathrm{X}_{3}=$ Value of fertilisers and pesticides (In ₹)

$X_{4}=$ Expenditure on irrigation ( $\ln ₹$ )

$X_{5}=$ Area under cultivation (In hectares)

$\mathrm{V}_{\text {it }}=$ Error term

The above frontier production function was estimated with double log specification by using Front 4.1 version. It was estimated for polluted and non-polluted areasseparately.

\section{Results and Discussion}

Types of Pollution in the Study Area : Farmers' responses pertaining to the existence of land, water, air and noise pollution were asked. They responded only for the land and water pollution. Hencethe responses of farmerspertaining to land and water pollution are discussed here.

Land Pollution: The farmers were asked to respond on land pollution. Table 1 shows the responses of the farmers.

Table 1: Responses of Farm Households on Land Pollution

\begin{tabular}{lccccc}
\hline & & & & & (In Numbers) \\
Area & Marginal & Small & Semi-medium & Medium and Large & Total \\
\hline Yes & $3(100)$ & $6(60)$ & $29(93.5)$ & $6(100)$ & $44(88)$ \\
No & 0 & $4(40)$ & $2(6.5)$ & 0 & $6(12)$ \\
Total & $3(100)$ & $10(100)$ & $31(100)$ & $6(100)$ & $50(100)$ \\
Non-polluted & & & & & \\
Yes & 0 & 0 & 0 & 0 & 0 \\
No & $7(100)$ & $6(100)$ & $23(100)$ & $14(100)$ & $50(100)$ \\
Total & $7(100)$ & $6(100)$ & $23(100)$ & $14(100)$ & $50(100)$ \\
\hline
\end{tabular}

Note: Figures in parentheses denote percentages to total farmers in each group.

In polluted area, all the marginal farmers (cent per cent), 60 per cent of the small farmers, 93.5 per cent of the semi-medium farmers and all the medium and large farmers (cent per cent) had responded on land pollution. When all categories of the farmers were taken together,
88 per cent of the farmers had responded. According to them, land pollution was caused due to existence of industries. In non-polluted area, none of the farm householdshad responded.

Water Pollution: Table 2 shows the farmers' responses pertaining to water pollution.

Table 2: Responses of Farm Households on Water Pollution

\begin{tabular}{lccccc}
\hline $\begin{array}{l}\text { Area } \\
\text { Polluted }\end{array}$ & Marginal & Small & Semi-medium & Medium and Large & Total \\
\hline Yes & $3(100)$ & $10(100)$ & $31(100)$ & $6(100)$ & $50(100)$ \\
\hline & & & & & (Contd........)
\end{tabular}

Journal of Rural Development, Vol. 36, No. 2, April - June : 2017 
Table 2 (Contd.....)

\begin{tabular}{lccccc}
\hline $\begin{array}{l}\text { Area } \\
\text { Polluted }\end{array}$ & Marginal & Small & Semi-medium & Medium and Large & Total \\
\hline No & 0 & 0 & 0 & 0 & 0 \\
$\begin{array}{l}\text { Total } \\
\text { Non-polluted }\end{array}$ & $3(100)$ & $10(100)$ & $31(100)$ & $6(100)$ & $50(100)$ \\
Yes & 0 & 0 & 0 & & \\
Marginal & Small & Semi-mediumMedium and Large & Total & \\
Polluted & $7(100)$ & $6(100)$ & $23(100)$ & $14(100)$ & $50(100)$ \\
No & $7(100)$ & $6(100)$ & $23(100)$ & $14(100)$ & $50(100)$ \\
Total & &
\end{tabular}

Note: Figures in parentheses denote percentages to total of farmers in each group.

In polluted area, all the marginal, small, semi-medium, medium and large farmers had responded on water pollution. The wastes of dyeing factory in Tiruppur were disposed in the Noyyal river which was flowing through the Orathuppalayam dam in the study area. The disposed dyeing wastes in the dam through the river polluted the dam water. The dam water was used for irrigation purpose. Moreover, the blocked wastes in the dam affected the fertility of the soil and quality of the ground water. None of the farm households in non-polluted area had responded on water pollution.

Based on the order of the high court, ₹ 62.38 crore were collected from polluters towards compensation. The amount is yet to reach the 11968 farmers who were affected by the pollution from the industries.

\section{Consequences of Dyeing Industrial Pollution in Polluted Area}

Various consequences of industrial pollution such as dumping of industrial wastes, change in the colour of water, mixing of dyeing wastes in the water, mixing of drainage into the river water, decline in the quality of water and not able to use for agriculture, decline in the quality of land, burning of crops, not able to use water for livestock for drinking, soil erosion, conversion of agricultural land into industrial land, mixing of waste in canal water, decline in the water tableand decline in the frequency of the rainfall were ranked by the farm households. The above ranks were classified as high preference and low preference factors. Table 3 shows the number of farmers responded for high preference for the above-mentioned factors in polluted area.

Table 3: Consequences of Industrial Pollution

\begin{tabular}{lcccccc}
\hline Consequences & Marginal & Small & $\begin{array}{c}\text { Semi- } \\
\text { medium }\end{array}$ & \multicolumn{2}{c}{$\begin{array}{c}\text { Medium } \\
\text { and Large }\end{array}$} & Total \\
\hline Dumping of industrial wastes & $3(100)$ & $10(100)$ & $31(100)$ & $6(100)$ & $50(100)$ \\
Change in the colour of water & $1(33.33)$ & $2(20)$ & $17(54.83)$ & $3(50)$ & $23(46)$ \\
\hline
\end{tabular}

Journal of Rural Development, Vol. 36, No. 2, April - June: 2017 
S. Gandhimathi and N.Dhanabaghiyam

Table 3 (Contd.....)

\begin{tabular}{|c|c|c|c|c|c|}
\hline Consequences & Marginal & Small & $\begin{array}{l}\text { Semi- } \\
\text { medium }\end{array}$ & $\begin{array}{l}\text { Medium } \\
\text { and Large }\end{array}$ & Total \\
\hline $\begin{array}{l}\text { Mixing of dyeing wastes } \\
\text { in the water }\end{array}$ & $2(66.66)$ & $8(80)$ & $23(74.19)$ & $6(100)$ & $39(78)$ \\
\hline $\begin{array}{l}\text { Mixing of drainage into } \\
\text { the river water }\end{array}$ & $2(66.66)$ & $1(10)$ & $17(54.83)$ & $3(50)$ & $23(46)$ \\
\hline $\begin{array}{l}\text { Decline in the quality of } \\
\text { water and not able to use for } \\
\text { agriculture }\end{array}$ & $1(33.33)$ & $2(20)$ & $15(48.38)$ & $3(50)$ & $21(42)$ \\
\hline $\begin{array}{l}\text { Decline in the } \\
\text { quality of land }\end{array}$ & $1(33.33)$ & $7(70)$ & $24(77.41)$ & $1(16.66)$ & $33(66)$ \\
\hline Burning of crops & $2(66.66)$ & $9(90)$ & $23(74.41)$ & $4(66.66)$ & $38(76)$ \\
\hline $\begin{array}{l}\text { Not able to use water } \\
\text { for livestock }\end{array}$ & $2(66.66)$ & $7(70)$ & $23(74.19)$ & $4(66.66)$ & $36(72)$ \\
\hline Soil erosion & $3(100)$ & $9(90)$ & 19(61.29) & $4(66.66)$ & $35(70)$ \\
\hline $\begin{array}{l}\text { Conversion of agricultural } \\
\text { land into industrial land }\end{array}$ & $1(33.33)$ & $4(40)$ & $12(38.70)$ & $4(66.66)$ & $21(42)$ \\
\hline Mixing of waste in canal water & $1(33.33)$ & $7(70)$ & $13(41.93)$ & $3(50)$ & $24(48)$ \\
\hline Decline in the water table & $2(66.66)$ & $7(70)$ & $19(61.29)$ & $4(66.66)$ & $32(64)$ \\
\hline $\begin{array}{l}\text { Decline in the frequency of } \\
\text { rainfall }\end{array}$ & $1(33.33)$ & $4(40)$ & $7(22.58)$ & $2(33.33)$ & $14(28)$ \\
\hline
\end{tabular}

Note: Figures in parentheses denote percentages to total farmers in each group.

In polluted area, all the households of marginal, small, semi-medium, medium and large farmers had said that there was dumping of industrial waste. Around 67 per cent of the marginal farmers, 80 percent of the small farmers, 74.19 per cent of the semi-medium farmers and cent per cent of the medium and large farmers reported mixing of dyeing waste in the water. Similarly, decline in the quality of land was responded by 33.33 per cent of the marginal farmers, 70 per cent of the small farmers, 77.41 percent of the semi-medium farmersand around 17 percent of medium and large farmers. More than 60 per cent of the farm households in polluted area had responded burning of crops, not able to use water for livestock for drinking, soil erosion and decline of water table as the consequences of dyeing industrial pollution. The factors such as change in the colour of water, mixing the drainage into the river water, decline in the water quality which was not able to use for agriculture, conversion of agricultural land into industrial land, mixing of waste into canal water and decline in the frequency of rainfall were responded by less than 50 per cent of the farm households.

The above statistical facts revealed that the dumping of industrial waste was the major 
contributor of industrial pollution followed by mixing of dyeing waste into the water, burning of crops, not able to use water for livestock for drinking, soil erosion and decline in the quality of land and water table.

\section{Impact of Dyeing Industrial Pollution on Production Function}

The frontier production function was estimated to identify the impact of dyeing industrial pollution on production function in agriculture. The frontier production function is a mathematical form which gives the maximum output attainable for a given level of inputs. Hence the upper level of output is the frontier output. Hence, the farmers using a common technology produce the output below the frontier output and not above it. The degree to which the sample farmers fall short of the frontier output provides a logical measure of technical efficiency (Taylor and Shonkwiler, 1986).

To identify the impact of dyeing industrial pollution on production function, frontier production function was estimated for farmers in polluted and non-polluted areas. The estimated results of stochastic frontier production function forfarmers in polluted area are shown in Table 4.

Table 4: Frontier Production Function of Farmers in Polluted Area

\begin{tabular}{lccc}
\hline Variables & Maximum Likelihood Co-efficient & t value & Significant Level \\
\hline Constant & 6.1102172 & 2.4647351 & Significant at 5\% level \\
Labour & 0.30179066 & 0.87738395 & Insignificant \\
Seeds & 0.0020568683 & 0.020166892 & Insignificant \\
Fertilisersand pesticides & 0.074833068 & 0.30348444 & Insignificant \\
Expenditure on irrigation & 0.29105242 & 1.9069017 & Insignificant \\
Areaundercultivation & 0.31 & 0.2148 & Insignificant \\
Mean technical efficiency & & & \\
\hline
\end{tabular}

The estimated frontier production function coefficients of expenses on labour,seeds, fertilisers, pesticides, irrigation and area under cultivation were statistically insignificant. It implied that the farmers were not able to allocate all the above inputs efficiently. The mean technical efficiency of farmers in the polluted area was 0.46 . The value of log likelihood ratio test (LR test) was insignificant in the production function of polluted area. (LR test $=0.2170)$. It proved the existence of technical inefficiency in the production function. The estimated results of stochastic frontier production function for nonpolluted area is shown in Table 5.

Table 5: Frontier Production Function of Farmers in Non-polluted Area

\begin{tabular}{lccc}
\hline Variables & $\begin{array}{c}\text { Maximum Likelihood } \\
\text { Co- efficient }\end{array}$ & t value & Significant Level \\
\hline Constant & 6.1153485 & 2.652929 & Significant at 5\% level \\
Labour & 0.30177785 & 0.97883999 & Insignificant \\
\hline & & & (Contd........)
\end{tabular}

Journal of Rural Development, Vol. 36, No. 2, April - June : 2017 
Table 5 (Contd.....)

\begin{tabular}{|c|c|c|c|}
\hline Variables & $\begin{array}{l}\text { Maximum Likelihood } \\
\text { Co- efficient }\end{array}$ & tvalue & Significant Level \\
\hline Seeds & 0.0020541877 & 0.021521263 & Insignificant \\
\hline Fertilisers and pesticides & 0.074843955 & 0.33485234 & Insignificant \\
\hline Expenditure on irrigation & 0.2910393 & 2.1488775 & Significant at $5 \%$ level \\
\hline Areaunder cultivation & 0.63 & 3.149 & Significant at $5 \%$ level \\
\hline Mean technical efficiency & 0.9 & & \\
\hline
\end{tabular}

For the farmers in non-polluted area, the estimated frontier production function coefficient of expenditure on irrigation and area under cultivation were statistically significant. It revealed that additional amount of expenses on irrigation and additional area under cultivation could contribute to additional production of farmers. The other input coefficient such as value of labour, seeds and value of fertilisers and pesticides turned out to be statistically insignificant. It also revealed absence of technical efficiency pertaining to the above inputs in the non-polluted area. The log likelihood ratio test was also statistically significant. It proved the existence of technical efficiency in the production function of farmers in non-polluted area. The mean technical efficiency in the production function of farmers in non-polluted area was higher (0.97) than in the production function of farmers in polluted area (0.46). It showed better allocation of inputs in the production function of farmers in non-polluted area than in the production function of farmers in polluted area.

\section{Impact of Industrial Pollution on Farm Income}

The industrial pollution had changed the cropping pattern and agricultural lands were converted into industrial lands. Hence, the cropping pattern of farm households had changed. This change had affected the farm income. Henceto identify the impact of industrial pollution on farm income in the study area, the industrial pollution along with the age of the farmer head, asset holding, farm expenses and area under cultivation were put into the multiple regression analysis. The results of the regression analysis are shown in Table 6.

Table 6: Impact of Industrial Pollution on Farm Income-Regression Analysis

\begin{tabular}{lccl}
\hline Model & Regression Coefficients & t value & Significant Level \\
\hline (Constant) & 33170.019 & -.211 & Insignificant \\
Industrial pollution & -324644.196 & -6.397 & Significant at 1\% level \\
Age & 1314.993 & .826 & Insignificant \\
Farm assets & 0.020 & 3.843 & Significant at 1\% level \\
Farm expenses & 3.204 & 8.838 & Significant at 1\% level \\
Areaundercultivation & 1.234 & 0.311 & Insignificant \\
Rsquare & \multicolumn{2}{c}{0.52} & \\
Fvalue & 20.34 & Significant at 1\% level \\
\hline
\end{tabular}

Note: Dependent Variable = Farm Income. 
Theestimated farm income equation was statistically significant at one percentage level. It could be identified from the significant $F$ value. Hence, the selected independent factors were able to explain the farm income equation significantly. The value of $R^{2}$ was 0.52 in the farm income equation. It implied that the farm income of farm households was explained by 52 percent by the selected independent factors. The factors such as industrial pollution, asset holding and farm expenses were statistically significant at one per cent level. Among the above factors, the coefficient of industrial pollution wasnegative. It implied that the increase in the industrial pollution caused decline in the farm income. The coefficient of industrial pollution was 324644.196. It means that if one additional farmer cultivated in industrial polluted area, the farm income of the farmers would decline by $₹ 324644.196$. The coefficient of asset holding and farm expenses were positive. It reveals that additional asset holding and farm expenseswould increase the farm income. The age of the farmer head was statistically insignificant to determine farm income.

\section{Conclusion}

The Orathuppalayam dam was constructed in 1992. It irrigated over 10,000 acres in Tiruppur and Karur districts. It was used by the farmers only for five years as it became a storage tank for textile effluents after that. The farmers, in Orathuppalayam village were not able to cultivate in their land as the ground water and dam water were polluted. Hence all the farmers had responded that the dumping of industrial waste impacted on agriculture. The quality of land was completely eroded and the crops were burnt due to dyeing industrial pollution. The water could not be used for livestock for drinking purpose. Moreover, the ground water table had declined. Before the dyeing industries were established in Tiruppur,crops such as paddy, all kinds of vegetables, banana, turmeric and cotton were cultivated in Orathuppalayam village. But now the old cropping pattern disappeared. Only maize and coconut are cultivated.The farmers in polluted area werenot ableto allocate farm inputs more efficiently. Hence, less technical efficiency was observed in the production function of polluted area. 


\section{References}

1. Aragon and Poblo Rud (2012), “Mining, Pollution and Agricultural Productivity: Evidence from Ghana,"pp. 1-59.

2. Chakrabarty (2011), "Agricultural Productivity - Issues and Way Forward," Annual Report 2011.www.rbi.org

3. Dhurjati Mukherjee (2012), "Agriculture and Climate Change", Kurukshetra, J une, Vol.60, No.8, pp. 18-21.

4. Government of India, (2012), "State of Indian Agriculture Report 2011-12", Ministry of Agriculture, New Delhi.

5. Maharajan, K and Kirubakaran Samual (2011), "Impact of Environmental Pollution on Health."

6. Priya (2013), "Impact of Industrial Pollution on Agriculture in Coimbatore District," Unpublished M. Phil Thesis, Department of Economics, Avinashilingam Institute for Home Science and Higher Education for Women University.

7. Ram, Naresh (2011), "Ground Water Pollution due to Overuse of Nitrogenous Fertilizers," Financing Agriculture, December, Vol.43, No: 12, pp. 24-25.

8. Reserve Bank of India(2013), "Handbook of Indian Economy,” www.rbi.org/publications

9. Sambasivam, K and Abdulraheem, A (2012), "Climate Change Impacts on Agriculture Sector."

10. Shabir Ahmad, Padder (2013), "Climate Change - Impact on Agriculture”, Kurukshetra, J une, 2013.

11. Shivkumar Biradar (2012), "Environmental Challenges \& Issues of Indian Agriculture," Kurukshetra, June, Vol.60, No.8, pp. 30-34.

12. Sivasankaraiah M, Thulasi Naik and Dasaratharamaiah (2008), "Environmental Pollution: Effects, Causes and Concerns", Southern Economist, J une, Vol.47, No.3, pp. 13-16.

13. --------- -Sociological Study in Tuticorin Industrial Town, TN, India" Journal of Ecobiotechnology, October, Vol. 2 No.2, pp.51-56.

14. - - - - - - - - "SomeEvidences,"Radix International Journal of Research in Social Science, October, Vol. 1 No.10, pp. 1-14.

15. Taylor, G and Shonkwiler,J (1986), "Alternative Stochastic Specifications of the Frontier Production Function in the Analysis of Agricultural Credit Programs and Technical Efficiency", Journal of DevelopmentEconomics, Vol.21, Issue.1, pp.149-160. 